\title{
Diachronic Analysis of Stance Markers in Research Articles' discussion Sections
}

\author{
1, *Davud Kuhi; ${ }^{2}$ Shirin Rezaei \\ ${ }^{1,2}$ Islamic Azad University, Iran \\ *Corresponding author: davudkuhi@yahoo.com
}

\begin{abstract}
It is now increasingly accepted that metadiscourse as one of the significant rhetorical features of research articles is context-sensitive and subject to change in response to the historically developing practices of academic communities. Motivated by such an understanding, the current research drew on a corpus of 914679 words taken from three leading journals of applied linguistics in order to trace the diachronic evolution of stance markers in discussion sections of research articles from 1996 to 2016. The analysis revealed a substantial decline in the overall frequency of stance markers in discussion section, with devices in all categories, except self-mention which increased dramatically over the past 20 years. Approaching the interactional dimension of academic writing from such a diachronic perspective, it might be argued that academic writing reflects, and in turn constitutes, social and institutional practices derived from contexts which are continually changing. Hence, training in academic writing needs to be a process of raising students' consciousness of the choices they can make and the consequences of making those choices in particular contexts.
\end{abstract}

Keywords: Applied Linguistics, Diachronic, Metadiscourse, Stance, Discussion.

\section{Introduction}

Disciplines are not stable. They keep becoming highly complex and even more dynamic; they are shifting, boundaries are changing and there are more subdisciplines than ever (Trowler, 2012). However, it is not well-known or fully agreedupon why disciplines evolve and which factors contribute to their evolution. What is generally accepted by now is that academic disciplines are subject to historical, geographical, political, and economic variations and evolve in response to the threats to their existence (Becher \& Trowler, 2001).

Several studies have addressed the major contributing factors thought to influence the evolution of disciplines and have particularly emphasized specialization, 
globalization, massification, regulation, market-forces, fragmentation and technology (see, for example, Stichweh, 2001; Becher \&Trowler, 2001; Vashishitha, 2014; Trowler, Saunders, and Bamber 2012, Cohen \& Lloyd, 2014).

Stichweh (1996), for instance, has contributed to our understanding of the dynamic nature of disciplines by highlighting the fact that the first premise for the rise of disciplines as communication systems is the specialization of scientists and the role differentiation attendant on it. For him, dynamicity of this modern system results from the intensification of the interactions between ever more disciplines.

Following a similar logic, Vashishitha (2009) highlights the process of specialization to track the evolution of disciplines. From his point of view, the evolutionary history of disciplines could be explained by the following path: 1. Knowledge, 2 . Specialization and Fragmentation of knowledge, 3. Discipline ,4. Diversification and further specialization of knowledge within the discipline, 5. Breaking of disciplinary boundaries and emergence of more specialized new disciplines. In his view, development of the disciplines has been an ongoing process in which the basis of knowledge forms into a specialization.

Krishnan (2009) based his argument on the assumption that the evolution of academic disciplines cannot be understood without reference to the historical context. A central aspect of his view is that particular political and societal needs have given rise to new disciplines and subsequently their changes can get disciplines into trouble. Moreover, in a recent attempt to show the dynamic nature of disciplines, Cohen \& Lloyd (2014) make an analogy between biological evolution and disciplinary evolution, and argue that, like life forms, disciplines mature, develop, and move toward extinction due to changes in the environment. They conclude that the availability of technology, particularly information technology has had great impact on many disciplines and has led to new disciplines being developed.

In a more comprehensive study, Becher and Trowler (2001) have identified six structural changes which have great influence on "academic tribes" and their "territories". These changes are identified as globalization, massification, regulation, market-orientation, efficiency, and fragmentation. In fact, their study refers to the ways in which current structural changes and epistemic shifts prepare the ground for new games and new rules to play by: globalization and market-orientation challenge academic borders; mass orientation and fragmentation invite new types of agents and institutions; the traditional academic disciplines dissolve; and an epistemic diversity is now the norm. 
Moving on the same track, Trowler, Saunders, and Bamber (2012) recognize other powerful structures such as technologies and managerialist ideology and practices as well as the significance of agency in disciplinary articulation.

The studies reported above reveal the fact that academic disciplines are malleable, open, natural systems influenced in contextually-contingent ways by social and material characteristics (Trowler, 2012). This revised view of disciplines has provided some unique implications for academic practices in that they "have moved from being very loosely coupled to relatively tightly coupled to outside degerminators in which external and imperative increasingly exert influence on how academics behave and what they think is important" (Trowler, 2012).

The complexity, fuzziness, and dynamism of applied linguistics (AL) as an academic discipline cannot be seen as so distinct from other disciplines (see for example, Brurmfit, 2004; Bygate, 2005; Kaplan, 2002). The most interesting topic in the history of AL which is regarded as "a major paradigm shift" (Rajagopalan, 2004) is the way it evolved from a dependent field - primarily concerned with applying insights from linguistic theory - to an autonomous field of inquiry. In fact, a realistic history of the field of applied linguistics would place its origins at around the year 1948, exclusively constrained to teaching English. Then in the early 1980s, Widdowson (1984) inspiringly proposed that applied linguistics should think of its own identity, instead of merely applying insights from linguistics to pedagogy. In fact, Widdowson's proposal called attention of AL researchers to declare the autonomy of their discipline. What this declaration meant was that researchers recognized the need to turn to other disciplines in addition to linguistics in order to formulate their own theoretical frameworks.

Hence, AL was slowly being transformed into an interdisciplinary field. But, as Grabe (2010) argues, applied linguistics evolved still further during the 1990s and 2000 s, breaking away from the common framing mechanisms of the 1980s. In fact, the 1990s were marked by a growing awareness of the need to conceive of AL as a transdisciplinary field of inquiry which was philosophically influential in the history of the evolution of $\mathrm{AL}$ as an autonomous discipline. This meant "traversing conventional disciplinary boundaries to develop a brand-new research agenda which, while freely drawing on a wide variety of disciplines, would remain subaltern to none" (Rajagopalan, 2004: p.429). In this perspective, the rise of a transdisciplinary character can be described as a liberating force, one which frees academics from the confines of the disciplinary cages which have been used to regulate and control them (Manathunga \& Brew, citing Smith 1999). 
Conceiving of applied linguistics as a transdisciplinary field of inquiry might have significant implications and influences on various aspects of the field. One such issue is related to different ways in which knowledge is produced and evaluated. According to Notwotny et al. (2001) transdiscipliniarity reflects current modes of knowledge production in the 'Mode 2 society'; it is non-hierarchical and dynamic, appreciating that areas of current understanding are expanding, changing, and developing over time. Rip (2004) describes this knowledge by using the metaphor of "reservoir" in which researchers fish... to create new understanding, technology and options. In fact, transdiscipliniarity explicitly sets its knowledge production not only around disciplinary problem-definitions but also around other definitions, derived from pressures, 'applications' or from societal stakeholders.

In this way, the research conducted in transdisciplinary context is "carried out in application", "created in broader ... social and economic contexts" and also takes into account the criteria of whether the solution found in praxis will "be competitive on the market ... cost effective" or "socially acceptable" (Gibbons et al. 1994, p. 38). This has led to the view that interdiscipliniarity and transdiscipliniarity are essentially a conservative force which pushes research and other academic practices in directions preferred by capitalist interests (Trowler 2012). For example, the growth of scientism in applied linguistic practices as a sign of the shift from mode 1 to mode 2 knowledge may not be unrelated to the researchers' need to adopt a market-driven discourse under pressures of new audiences outside a traditional peer group like funding resources, publishers, and other academic and nonacademic institutions.

It should be mentioned here that what we have outlined above could not take place without the constructive and constitutive functioning of the discourses of the discipline. Amongst the academic genres, research article (RA) as the "master narrative of our time" constitutes the most important channel for the presentation of new disciplinary knowledge (Hyland, 2000a; Salager-Meyer, 2001; Swales, 1990; Swales, 2004). Hence, as disciplines and their academic practices have continued to evolve, so too have the research articles by which their findings are primarily communicated. Accordingly, metadiscourse resources as one of the significant features of RAs have also gone through the same diachronic evolution process to fulfill new social and epistemological demands of discourse communities (Gillaerts \& Van de Velde, 2010; Gillaerts, 2014; Kuhi \& Mousavi, 2015; Hyland\& Jiang, 2016a, 2016b, 2018a; Kuhi \& Dust-Sedigh, 2012). These studies meaningfully expand our knowledge of metadiscourse variation across disciplines and languages over time. A specific strength of all the studies is the discussion of connections between discourse variation and social practices of discourse communities. 
From Hyland and Jiang' s (2016) point of view, successful research writers construct texts by taking a novel point of view toward the issues they discuss while anticipating readers' imagined reactions to those views. According to Hyland and Jiang (2016), "this intersubjective positioning is encompassed by the term stance and, in various guises, has been a topic of interest to researchers of written communication and applied linguists for the past three decades" (p.1). Stance is a rhetorical choice that allows authors to conduct interpersonal negotiations and balance claims for the significance, originality, and plausibility of their work against the convictions and expectations of their readers. However, like other features of disciplinary discourses, it is not a static and unchanging marker of professional research writing. In fact, over time, taken-for-granted conventions of disciplinary discursive practices constantly shift in response to changes in the dominant socio-cultural forces in society. Although this dynamic and unpredictable discursive practice may result in a feeling of uneasiness among those accustomed to teaching and learning fixed conventions of communication in academic English, negligence of this dynamicity can result in their considerable trouble in adapting their rhetorical practices to such changes, particularly in EFL contexts.

Informed by the line of thought outlined above, the current study drew on a corpus of 914679 words taken from three leading journals of applied linguistics to investigate whether, and to what extent, stance markers have changed inside a single discipline in the discussion section of research articles published in three leading journals of applied linguistics (Applied Linguistics, English for Specific Purposes, Modern Language Journal) during the two decades from 1996 to 2016. More specifically, our study attempted to answer the following research question:

Has the frequency of occurrence of stance markers changed in discussion section of research articles published in three leading journals of applied linguistics (Applied linguistics, English for Specific Purposes, Modern Language Journal) between 1996 and 2016?

\section{Methodology}

\section{Corpus}

The corpus of this study consisted of approximately 914679 words. Research articles taken from three leading journals in applied linguistic discipline (Applied Linguistics journal, English for Specific Purposes journal, Modern Language Journal) created three corpora in three periods over the past 20 years: 1996-2002, 2003-2009 and 2010-2016 as shown in Table 1 . The disciplinary scope of the corpus was restricted 
to applied linguistics as defined by Wilkins (1999) and outlined in some handbooks of applied linguistics (e.g., Kaplan, 2002; Schmitt, 2002; Davies \& Elder, 2004). The journals were selected on the basis of the three criteria set by Nwogu (1997): representativeness, reputation and accessibility. About 10 university lecturers in applied linguistics issues nominated eight journals based on the established tradition of selection and sampling in other metadiscourse studies - informant nomination (e.g., Harwood, 2005a, 2005b; Hyland, 1999a, 2001a, 2002a, 2002b, 2002e). However, in terms of accessibility, only these three journals could be retrieved online over a span of 20 years. In terms of representativeness and reputation, the three selected journals were all leading journals in applied linguistics, indexed in the SCI with an average impact factor (IF) of above 1.5.

Table 1

Corpus Size and Composition

\begin{tabular}{lllll}
\hline Journal & $96-2002$ & $2003-2009$ & $2009-2016$ & Overall \\
\hline AL & 266567 & 131482 & 1145420 & 1543469 \\
ESP & 294265 & 319858 & 459916 & 1074039 \\
MLJ & 419977 & 255855 & 1023514 & 1699346 \\
Overall & 980809 & 707195 & 2628850 & 4316854 \\
\hline
\end{tabular}

\section{Model of analysis}

Hyland's (2005b) model of metadiscourse was adopted for the analysis of the corpora. Based on the proposed model, the features included for the analysis were defined as follows: Stance refers to the "writer-oriented features" of interaction and concerns the ways writers comment on the accuracy of a claim, the extent they show their commitment to it, or the attitude they want to express to a proposition or the reader (Hyland, 2005b). It includes hedges, boosters, attitude markers and selfmentions:

- Hedges are used to indicate writers' decisions to withhold complete commitment to a proposition for example might, perhaps, possible.

- Boosters are employed by the writers to express certainty and emphasize the force of propositions for example in fact, definitely. 
- Attitude markers indicate the writers' affective and emotional, rather than epistemic, attitude to suggested propositions, conveying surprise, obligation, agreement, importance, and so on for example, unfortunately, I agree, surprisingly.

- Self-mentions signal authors' explicit presence in the text for example $I$, we, our, my.

\section{Procedure}

The compiled search items taken from the appendix of Hyland (2005b) (see Appendix) were manually examined and counted with rigorous consideration of possibly diverse functional values. Due to the pragmatic, internal, and multifunctional nature of metadiscourse items, the authors, working independently, coded a $10 \%$ sample to ensure reliability with $95 \%$ agreement. Cases of disagreement were discussed until a common decision was made. After reading and coding all the papers, the frequencies of stance markers were calculated (per 10,000 words). Chi-square test was then used to determine the statistical significances.

\section{Results and Discussion}

\section{Frequency of Stance Markers in Discussion Section}

As the findings reported in Table 2 indicates, hedges were found to have the highest proportion of use among the various types of stance features employed in discussion sections (591.5), followed by boosters (305.2), attitude markers (298.5), and finally self-mention which came last (92.4).

\section{Table 2}

Distribution of Stance Markers in discussion Section (1996-2016) (per 10,000 words).

\begin{tabular}{lllll}
\hline $\begin{array}{l}\text { Stance } \\
\text { Markers }\end{array}$ & $96-2002$ & $2003-9$ & $2010-16$ & Total \\
\hline Hedges & 210.8 & 188.7 & 192.1 & 591.6 \\
Boosters & 104.2 & 100.45 & 100.6 & 305.2 \\
Self-mentions & 27.3 & 21.6 & 43.5 & 92.4
\end{tabular}




$\begin{array}{lcccc}\begin{array}{l}\text { Attitude } \\ \text { markers }\end{array} & 105.1 & 100.8 & 92.6 & 298.5 \\ \text { Total } & 447.4 & 411.6 & 428.8\end{array}$

As Table 2 markedly shows, stance markers have fallen substantially, with devices in all categories, except self-mention which increased dramatically over the past 20 years $(\chi 2=8$, p-value $=0.01)$. This pattern can be explicitly seen in Figure 1 .

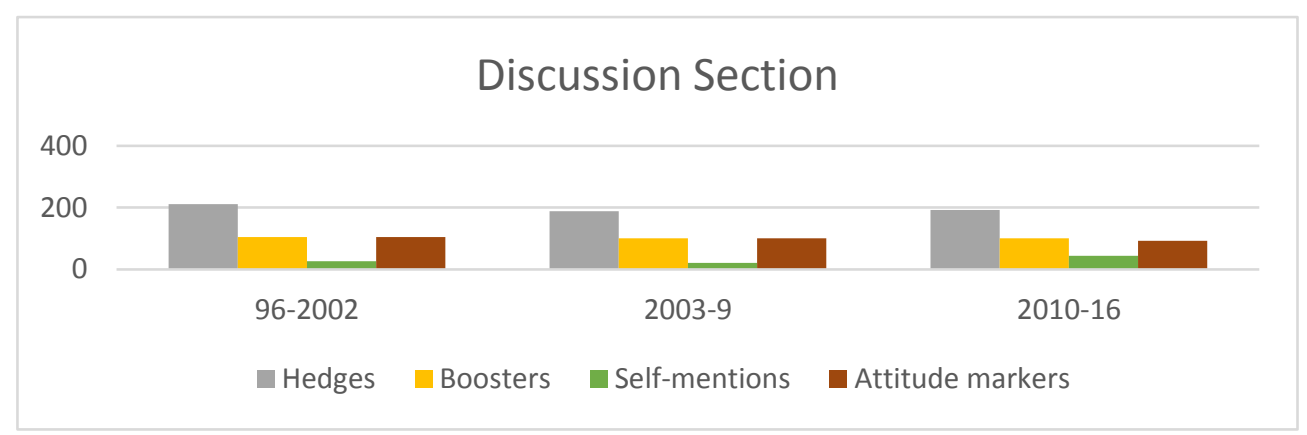

Figure 1. Distribution of Stance Markers in Discussion Section (1996-2016) (per 10,000 words)

In this article, we have tracked how stance markers have changed in discussion section of RAs published in three leading journals of applied linguistics (Applied Linguistics, English for Specific Purposes, Modern Language Journal) between 1996 and 2016. In fact, we witness writers' less use of these explicit markers than in the past. It is interesting to note that these findings are broadly consistent with those of Gillaerts and Van de Velde (2010), Gillaerts (2014), Hyland and Jiang (2016a, 2016b, 2018a).

Moreover, we have uncovered a somewhat surprising picture: while hedges, boosters, and attitude markers decreased substantially over time, self-mentions have undergone the greatest changes of all stance categories, increasing significantly over the past 20 years. This increase, mainly confined to plural forms might signal an increase in overt authorial role in interpretations of data and for claims of novelty (see Hyland \& Jiang, 2018). Harwood (2005b) observes that the pronouns I and we help to promote authors and their work found in both discussion and introduction sections of RAs. Such promotional devices can help repeat claims and findings at the close, to show that the work deserves to be taken seriously, and helps alert the readership to novelty. This quest for novelty has led some researchers (e.g., Haggan, 2004; Knorr-Cetina, 1981; Law and Williams, 1982) to describe the act of writing and publishing academic discourse in terms of more promotional types of discourse 
Thus, it might be argued that their massive rise in the discussion sections can enhance the development of a promotional and consumer-oriented discourse through establishing a stronger image of their self among their readers. In other words, tendencies towards a competitive, self-motivating, entrepreneurial self, dominated by the need to publish, to get claims accepted, and to secure funding and promotion, are reflected in the interactional features of published academic texts (Hyland, 2004). In fact, in modern academy, the academic writer's desire for promotion may plausibly be evidence for the emergence of commodified discourse due to a dramatic change in the nature of professionalism (Kuhi, 2014). Oswick and Hanlon (2009) characterize this change with professionals who are more commercially-driven and less willing or able to defend a notion of socially-oriented professionalism.

\section{Pedagogical implications}

Approaching the interactional dimension of academic writing from such a diachronic perspective indicates that while particular sets of conventions and practices of a discipline may be dominant in a given age, they are not permanent. On the basis of such assumptions, this study has a number of implications for teaching academic writing. First, it is clear that academic literacy is unlikely to be achieved through an orientation to some general academic conventions and practices. Writing cannot be understood solely in terms of either immediate situations of writing or from individual texts; rather, it reflects, and in turn constitutes, social and institutional practices derived from contexts which are constantly changing. However, the potential difficulties this rhetorical change creates for students and novice writers, particularly those writing in a second language can result in writers' considerable trouble in using metadiscourse devices. Consequently, this will lead to failure of representing self or one's ideas in the way that one intends Thus, training in academic writing should be seen as a process of raising students' consciousness of the choices they can make and the consequences of making those choices in particular contexts.

Along the same lines, online and other modes of discursive communication could also emerge, upon analyses such as this, to have certain genre-specific properties (Endong \& Essoh, 2015), and pedagogy in the modern era would do well to rise to the challenge and tap into these findings and insights for a more tailored approach to language instruction (Safari \& Sahragard, 2015). 


\section{References}

Anthony, L. (2011). AntConc 3.4.3. http://www.laurenceanthony.net/software.html.

Becher, T. \& Trowler, P.R. (2001). Academic Tribes and Territories. Intellectual enquiry and the culture of disciplines. Buckingham: Open University Press.

Brumfit, C. (2004). Applied linguistics in 2004: Unity in diversity? AILA Review, 17(1), 133136. DOI: 10.1075 /aila.17.12bru

Bygate, M. (2005). Applied linguistics: A pragmatic discipline, a generic discipline? Applied Linguistics, 26(4), 568-581. https://doi.org/10.1093/applin/ami032

Cohen, E. B., \& Lloyd, S. J. (2014). Disciplinary evolution and the rise of the transdiscipline informing science. the International Journal of an Emerging Transdiscipline, 17,189215.

Davies, A., \& Elder, C. (Eds.). (2004). The handbook of applied linguistics. Oxford, UK: Blackwell.

Endong, F. P. C. \& Essoh, N. E. G. (2015). Orality versus literacy in the Nigerian SMS discourse. Khazar Journal of Humanities and Social Sciences, 18 (3), 33-47. DOI: 10.5782/2223-2621.2015.18.3.33

Gibbons M, Limoges C, Nowotny H, Schwartzmann S, Scott P, Trow M. (1994). The new production of knowledge. Sage, London.

Gillaerts, P. (2013). Move analysis of abstracts from a diachronic perspective: a case study. In Johannesson, Nils-Lennart / Melchers, Gunnel / Björkmann, Beyza (Eds) Of butterflies and birds, of dialects and genres. Essays in honor of Philip Shaw.

Gillaerts, P. (2014). Shifting metadiscourse: Looking for diachrony in the abstract genre. In Bondi, M. \& Lores Sanz, R. (Eds.), Abstracts in academic discourse: Variation and change (pp. 271-286). Bern: Peter Lang.

Gillaerts, P., \& Van de Velde, F. (2010). Interactional metadiscourse in research article abstracts. Journal of English for Academic purposes, 9(2), 128-139.

Grabe. W (2010). Applied Linguistics: A Twenty-First-Century Discipline. In Kaplan, R. B. (Ed.). The Oxford handbook of applied linguistics. Oxford University Press.

Haggan, M. (2004). Research paper titles in literature, linguistics and science: Dimensions of attraction. Journal of pragmatics, 36(2), 293-317.

Harwood, N. (2005a). "We do not seem to have a theory . . . The theory I present here attempts to fill this gap": Inclusive and exclusive pronouns in academic writing. Applied Linguistics, 26, 343-375.

Harwood, N. (2005b). "Nowhere has anyone attempted . . .. In this article I aim to do just that": A corpus- based study of self-promotional I and we in academic writing across four disciplines. Journal of Pragmatics, 37, 1207-1231.

Hyland, K (1998a). Hedging in scientific research articles. Amsterdam: John Benjamins.

Hyland, K. (1999a). Talking to students: Metadiscourse in introductory textbooks. English for Specific Purposes, 18(1), 3-26.

Hyland, K. (1999b). Academic attribution: Citation and the construction of disciplinary knowledge. Applied Linguistics, 20, 341-367.

Hyland, K. (2001a). Humble servants of the discipline? Self-mention in research articles. English for Specific Purposes, 20, 207-226.

Hyland, K. (2001b). Bringing in the reader: addressee features in academic writing. Written 
Communication. 18. 549-574.

Hyland, K. (2002a). Directives: Argument and engagement in academic writing. Applied Linguistics, 23, 215-239.

Hyland, K. (2002b). Options of identity in academic writing. ELT Journal,56, 351- 358.

Hyland, K. (2002c). Genre: Language, context, and literacy. Annual Review of Applied Linguistics, 22, 113-135.

Hyland, K. (2002d). Specificity revisited: How far should we go now? English for Specific Purposes, 21, 385-395.

Hyland, K. (2002e). Activity and evaluation: Reporting practices in academic writing. In J. Flowerdew (Ed.), Academic discourse (pp. 115-130). White Plains, NY: Longman.

Hyland, K. (2004). Disciplinary discourses. Social interactions in academic writing. Ann Arbor, MI: The University of Michigan Press.

Hyland, K. (2005a). Metadiscourse: Exploring interaction in writing. London: Continuum.

Hyland, K. (2005b). Stance and engagement: A model of interaction in academic discourse. Discourse studies, 7(2), 173-192.

Hyland, K., \& Tse, P. (2004). Metadiscourse in academic writing: A reappraisal. Applied Linguistics, 25(2), 156-177.

Hyland, K., \& Jiang, F. K. (2016b). "We must conclude that...": A diachronic study of academic engagement. Journal of English for Academic Purposes, 24, 29-42.

Hyland, K., \& Jiang, F. K. (2018a). "In this paper we suggest": Changing patterns of disciplinary metadiscourse. English for Specific Purposes, 51, 18-30.

Kaplan, R. B. (2002). The Oxford handbook of applied linguistics. Oxford, UK: Oxford University Press.

Kaplan, R. B. (2010). The Oxford handbook of applied linguistics. Oxford University Press.

Kramsch, C. (2005). Foreign languages between knowledge and power. Applied Linguistics, 26(4), 545-567.

Kramsch, C. (2018). Trans-spatial utopias. Applied Linguistics, 39(1), 108-115.

Knorr-Cetina, K. (1981). The micro-sociological challenge of macro-sociology: Towards a reconstruction of social theory and methodology. In K. Knorr-Cetina \& A Cicourel (Eds.), Advances in social theory and methodology. Boston: Routledge and Paul.

Kuhi, D. (2014). Commodified discourses, commodifying discourses: In pursuit of a theoretical model on the constitutive functioning of academic discourse in marketization of higher education. Journal of Applied Linguistics and Discourse Analysis, 2(1), 39-62.

Kuhi, D. \& Dustsadigh, Z. (2012). A cross-cultural diachronic study on hedging devices diversity in chemistry research articles. Paper presented at the Second International Conference on Foreign Language Teaching and Applied Linguistics, Bosnia and Herzegovina, Sarajevo.

Kuhi, D. \& Mousavi, Z. (2015). A diachronic study of interpersonality in research article discussion section: The field of applied linguistics. International Journal of Research in Humanities and Social Studies, 2(4), 6-13.

Law, J., \& Williams, R. J. (1982). Putting facts together: A study of scientific persuasion. Social Studies of Science, 12(4), 535-558.

Manathunga, C., \& Brew, A. (2012). Beyond tribes and territories: New metaphors for new 
times. In Trowler, P., Saunders, M., \& Bamber, V. (Eds.), Tribes and territories in the 21st century: Rethinking the significance of disciplines in higher education. (pp. 4456). Routledge.

McNamara, T. (2015). Applied linguistics: The challenge of theory. Applied Linguistics, 36(4), 466-477.

Nwogu, K. N. (1997). The medical research paper: Structure and functions. English for Specific Purposes, 16(2), 119-138.

Nowotny, H., Scott, P., Gibbons, M., \& Scott, P. B. (2001). Re-thinking science: Knowledge and the public in an age of uncertainty. Cambridge: Polity.

Rajagopalan, K. (2005). "The Philosophy of Applied Linguistics". In D. Alan and C. Elder (Eds) The handbook of applied linguistics. 397-420. New York: Blackwell Publishing.

Rip, A. (2004). Strategic research, post-modern universities and research training. Higher Education Policy, 17(2), 153-166.

Safari, P. \& Sahragard, R. (2015). Iranian EFL Teachers' Challenges with the New ELT Program after the Reform: From Dream to Reality. Khazar Journal of Humanities and Social Sciences, 18 (4), 65-88. DOI: 10.5782/2223-2621.2015.18.4.65

Salager-Meyer, F. (2001). From self-highlightedness to self-effacement: a genre-based study of the socio-pragmatic function of criticism in medical discourse. LSP and Professional Communication 1(2).

Schmitt, N. (2002). An introduction to applied linguistics. New York: Arnold.

Stichweh, R. (2001). Scientific disciplines, History of. In N. J. Smelser \& P. B. Baltes (Eds.), International encyclopedia of the social and behavioral sciences (pp. 13727-13731). Oxford: Elsevier Science.

Trowler, P. (2012). Disciplines and academic practices. In P. Trowler, M. Saunders, \& V. Bamber (Eds.), Tribes and territories in the 21st century (pp.30-38). London: Routledge.

Trowler, P. (2014). Academic Tribes and Territories: the theoretical trajectory. Österreichische Zeitschrift Für Geschichtswissenschaften, 25(3), 17-26.

Trowler, P., Saunders, M., \& Bamber, V. (Eds.). (2012). Tribes and territories in the $21^{\text {st }}$ century: Rethinking the significance of disciplines in higher education. International studies in higher education. London; New York: Routledge.

Widdowson, H. G. (1984) 'Models and fictions'. in H. G. Widdowson (ed.), Explorations in applied linguistics 2, (pp. 21-27). Oxford: Oxford University Press.

Wilkins, D. A. (1999). Applied linguistics. In B. Spolsky (Ed.). Concise encyclopedia of educational linguistics (pp. 6-17). Amsterdam: Elsevier.

Vashishitha, PROF. U.C. (2014). Development of education as a discipline. (Doctoral dissertation). Retrieved from

http://shodhganga.inflibnet.ac.in/handle/10603/70652 


\section{Appendix}

\begin{tabular}{|c|}
\hline Stance Features \\
\hline Attitude Markers \\
\hline $\begin{array}{l}\text { admittedly; agree; agrees; agreed; amazed; amazing; amazingly; appropriate; } \\
\text { appropriately; astonished; astonishing; astonishingly; best; better; complex; } \\
\text { comprehensive; conclusively; consistent; correctly; c ritical; curious; curiously; } \\
\text { desirable; desirably; difficult; disappointed; disappointing; disappointingly; } \\
\text { disagree; disagreed; disagrees; dramatic; dramatically; essential; essentially; even } \\
\text { x; expected; expectedly; fortunate; fortunately; hopeful; hopefully; important; } \\
\text { importantly; inappropriate; inappropriately; interesting; interestingly; key; main; } \\
\text { major; meaningful; necessary; only; prefer; preferable; preferably; preferred; } \\
\text { remarkable; remarkably; robust; shocked; shocking; shockingly; significant; } \\
\text { striking; strikingly; surprised; surprising; surprisingly; unbelievable; } \\
\text { unbelievably; understandable; understandably; unexpected; unexpectedly; } \\
\text { unfortunate; unfortunately; unique; useful; unusual; unusually; usual; valuable. }\end{array}$ \\
\hline Boosters \\
\hline $\begin{array}{l}\text { actually; always; believe; believed; believes; beyond doubt; certain; certainly; } \\
\text { clear; clearly; conclude; conclusively; decidedly; definite; definitely; } \\
\text { demonstrate; demonstrated; demonstrates; determine; doubtless; emphasize; } \\
\text { establish; established; evident; evidently; find; finds; found; in fact; hold; } \\
\text { incontestable; incontestably; incontrovertible; incontrovertibly; indeed; } \\
\text { indisputable; indisputably; know; known; must; never; no doubt; obvious; } \\
\text { obviously; of course; primarily; prove; proved; proves; realize; realized; realizes; } \\
\text { really; revealed; show; showed; shown; shows; sure; surely; think; thinks; } \\
\text { thought; truly; true; undeniable; undeniably; underscore; undisputedly; } \\
\text { undoubtedly; without doubt }\end{array}$ \\
\hline He \\
\hline
\end{tabular}

about; almost; apparent; apparently; appear; appeared; appears; approximately; argue; argued; argues; around; assume; assumption; assumed; broadly; certain amount; certain extent; certain level; claim; claimed; claims; common; could; couldn't; doubt; doubtful; essentially; estimate; estimated; fairly; feel; feels; felt; frequently; from my perspective; from our perspective; from this perspective; generally; guess; hypothesis; hypothesized; indicate; indicated; indicates; in general; in most cases; in most instances; in my opinion; in my view; in this view; in our opinion; in our judgment; in our view; largely; likely; mainly; may; maybe; might; mostly; notion; often; on the whole; ought; partly; perhaps; plausible; 
plausibly; possible; possibly; postulate; postulated; postulates; presumable; presumably; probable; probably; proposed; quite; rather x; relatively; roughly; seems; should; sometimes; somewhat; suggest; suggested; suggests; suppose; supposed; supposes; suspect; suspects; tend to; tended to; tends to; tentatively; to my knowledge; typical; typically; uncertain; uncertainly; unclear; unclearly; unlikely; usually; virtually; view; would; wouldn't.

\section{Self-mentions}

I; we; our; us; me; my 